\title{
Income Smoothing: A Means for Organizational Survival
}

\author{
Obiaga, Johnson Chinedu (PhD) \\ Lecturer, Edwin Clark University \\ Ikiriko, Hope Odhuluma (PhD in-view) \\ University of Port Harcourt \\ Corresponding Author: Obiaga, Johnson Chinedu P.M.B 488 Uniport Post Office, \\ Port Harcourt, Rivers State, Nigeria
}

\begin{abstract}
This study examined the influence of income smoothing on organizational survival of selected quoted companies in Nigeria. The research study embraced the ex-post facto study design with a substantial dependence on secondary data produced from the annual reports of companies through 2007-2018. The population of the research study included 168 companies quoted on the Nigerian Stock Market (NSE) where a sample of 20 companies were attracted utilizing the judgmental sampling strategy. The Eview 9.0 analytical software application was utilized to examine the data. The research study wraps up that there is a connection in between the dimensions of income smoothing and organizational survival. Based upon the findings, the research study advises that appropriate and ideal procedure must be established for sufficient examination, evaluation and scrutinization of financial declarations of quoted companies. Likewise, the Nigerian Accounting Standard Board (NASB) ought to be more equipped to prepare a well-structured framework of accounting regulation, approve, review and examine financial declarations of all companies quoted on the Nigeria Stock market to guarantee conformity with GAAP, IFRS, CAMA and various other financial coverage Act. The paper advocates for extra strict supervisory system with operational implementation tools to ensure compliance with International Financial Reporting Standard and Auditing standards with the purpose of reducing income smoothing practices. The introduction of punitive measures could also assist in curbing the act of income smoothing amongst Nigerian companies.
\end{abstract}

Keywords: Income smoothing, Organizational survival, Nigerian Stock Market

DOI: $10.7176 /$ RJFA/12-14-04

Publication date:July $31^{\text {st }} 2021$

\section{Introduction}

The great need for sound economic and financing choices by resource providers in addition to other stakeholders leads to ever increasing demand for financial statements that are relevant to investors' in that they are accurately denoted and made available on time. Fund suppliers demand that financial report must accurately reveal the economic fact of actions and trades that occurred including provisions that subsisted at the reporting date.

Again, it is anticipated that stated revenues ought to strictly estimate the cash flows stemming from the conventional activities of the firm and cash flows from its capitalizing and sponsoring actions. Nevertheless, accounting humiliations such as Enron, WorldCom, Pamalat, Cadbury and others have a tendency to advise that the above anticipations are not constantly met by financial report presented by the managers of some corporations. It is considered that these humiliations ensued due to the deficiency of dependable and significant information required for reasonable conclusions (Idialu, 2008). Business directors, Bookkeepers and Account examiners are identified as standing at the heart of these humiliations which brought about agony to the financiers, workers and other interested party who at present shed doubt on the accounting vocation (Sunday et al., 2012). Income leveling/smoothing is the situation whereby managers states fake earnings. The yearning by managers to have remarkable accomplishment in their company is expected but the drawback is the method of achieving such targets.

Accountability and stewardship go hand in hand and on the other hand, transparency is vital when considering accountability. In the planning of account, company leaders are to confirm it presents the accurate stance of the activities of the business so as not to give deceptive information of the financial report to the public. The instances of Cadbury and other financial organizations including Intercontinental bank Plc, Oceanic bank Plc and Afribank Plc, Bank PHB and Spring bank who stage-managed their financial report, therefore, deceiving several users of their respective information, brought about questions on the theory of accountability (Idialu, 2008). This study is timely and relevant at least, for sealing this identified gap in literature which calls further attention to the danger of any "innovative" accounting practice on the growth and survival of any entity.

\section{Statement of the Problem}

Penman (2002) says that accounting quality have to be reviewed in relations to stakeholders' benefit and 
unbiased evaluation of that benefit. This then bring up the issue of equality as to the effect of income leveling/smoothing and whether this position of executives' acts to the utmost benefit of shareholders. Moreover, how does this falsification of revenues influence the performance of an organization? The misapplications of various financial reporting such as that of Enron, WorldCom, HealthSouth, Adelphia, have amassed doubts regarding the value of accounting information and the effect of such misapplications on the performance of organization (Wahlen et al, 2010). In Nigeria, the case of Cadbury, the insolvency of banks, stock market breakdown and fall of share prices steering to massive asset losses by shareholders sets a gallant doubt on the quality of financial reporting and waters the desire of scholars on the necessity to examine the actions of managers and its reported effects on the survival of firms.

Historical survey suggests that managers intentionally manipulate financial reporting technique by revealing earnings records that comply with estimated standards (Burgstahler \& Dichev, 1997; Zeckhauser \& Patel, 1999; Tapia \& Fernández, 2007). It is implied that earnings are more acceptable when the quality is greater as indicated by Joo (1991), there have been a few spurs for the phenomenon of income smoothing, for example, increasing investors welfare, encouraging the ability of envisaging income and upgrading the manager's welfare. Past research was principally in industrialized nations and Asian countries, with practically zero experimental research in third world economies, for example, Nigeria. With the insertion of International Accounting Standards, for example, IFRS, there is the need to reconsider some of these researched areas as the application of standards could have a sway on the reporting attitude of firms which were lacking under GAAP and may likely affect the study's result. In Nigeria there is a dearth in study about the impact of income smoothing on survival of organization. This study endeavors to fill this gap and set up whether organization survival can be impacted by income smoothing. Hence, the study is aimed at empirically investigating the effect of income smoothing on organization survival of quoted companies in Nigeria.

\section{Objectives of the study}

The mandate of this study was to examine the effects of income smoothing on organizational survival in Nigeria. Hence, the objectives to help achieve this mandate are to:

(i) analyze the effect of income smoothing on organizational profitability of quoted companies in Nigeria, and;

(ii) examine the impact of income smoothing on shareholders' wealth of quoted companies in Nigeria.

\section{Research Hypotheses}

Based on the specific objectives, the following null hypotheses are to be tested in this study:

$\mathbf{H}_{01}$ : There is no significant effect of income smoothing on organizational profitability of quoted companies in Nigeria.

Ho2: There is no significant impact of income smoothing on shareholders wealth of quoted companies in Nigeria.

\section{Review of Related Literature}

This phase of the research paper encompasses the evaluation of published materials relating to income smoothing and organizational survival. The assessment of related works in this study will include an importance on the theoretical foundation and conceptual framework carried out on income smoothing and organizational survival.

\section{Theoretical Foundation}

There are numerous theoretical viewpoints on income smoothing readily available to scholars in checking out the concern of income smoothing. This segment itemizes and examines the importance of the subsequent philosophies: agency theory, stewardship theory and information asymmetry theory.

\section{Agency Theory}

This research paper is secured on the Agency Theory. Agency theory has its origins in financial theory exposited by Alchian and Demsetz (1972). Nevertheless, it was introduced originally by Ross (1973) and amplified by Jensen and Meckling (1976) as quoted by Amat and Gowtharpe (2010). This theory is applied to fathom the connections where an individual or team of individuals (the principal) engages the skills of a different person or group of persons (the agent/representative) to execute some actions on their behalf. In doing so the principal entrusts the managerial power to the representative. This is commonly referred to as an agency connection.

The philosophy affirms that issues are certain to occur in any organization when one group (principal) engages with a different group (the agent/representative) to make choices on behalf of the principal (Michael, Peter, Sven-Olaf, \& Philippe, 2005). Nonetheless, the representative (supervisor) acts in a selfish way to make best use of his/her wealth to the impairment of the principal (investor). Consequently, there is a transference of wealth from the firm to the supervisor (Jensen \& Meckling, 1976). According to this theory, supervisors work 
towards taking full advantage of their individual value to the disadvantage of other shareholders. In order to decrease this practice and encourage them to look after the ideal business management, managers are paid according to accomplished outcome.

\section{Theory of Stewardship}

Stewardship theory proposes that managers/supervisors are inspired by a need to accomplish and achieve deeprooted fulfillment by executing difficult responsibilities; thus, their drive surpasses financial deliberations. Stewardship theory identifies the requirement for senior management to take steps even more independently to increase the investors returns. As a result, managers have need of authority and yearn for respect from employers and colleagues to efficiently accomplish their duties. For this reason, shareholders ought to approve the suitable enabling governance structure, systems, authority and information to expedite managers' independence, created on trust, to take choices that would certainly reduce their obligation while accomplishing company's goals (Donaldson \& Davis, 1991).

Unlike agency theory, stewardship theory stresses the function of top executives as guardians since they are required to incorporate their objectives as part of the company. Daily, Dalton, and Canella (2003) discuss that senior managers are inclined to shield their online reputations by making sure that their companies are effectively run to take full advantage of financial efficiency. Managers are required to increase stakeholder's revenue and to develop a high-quality status to allow them maintain their places (Shleifer \& Vishny, 1997). Hence, stewardship theory support merging the function of the Chief Executive Officer and the chairman to decrease agency fees (Abdullah \& Valentine, 2009). In addition, Dalton, Daily and Ellstrand (1999) emphasize five elements of management viewpoint of stewardship: trust, open interaction, empowerment, lasting orientation and efficiency improvement.

\section{Information Asymmetry Theory}

According to Ardekani, Nejat and Hashemijo (2012), the theory asserts that there is a likelihood of information irregularities in which the supervisor has far better information regarding the financial standpoint of the firm than the shareholders and various other individuals. From the educational point of view, the information irregularities produce a problem between privileged supervisors and stakeholders. The presumption is that the accounting revelations include information that is useful and relevant to stakeholders in offering signals. The accounting professional needs to represent a factual and unbiased analysis of trades in the accounting reports. The supervisors owing to the advantaged information and supervisory status capitalize or oversee the business into a path appropriate to them. They further affirmed that the efficacy of the secondary dealing of debt securities is boosted by reducing information irregularities pertaining to a debtor by way of conventional reporting. Accounting conservatism and accrual accounting can be tolls of innovative accounting as they have precise impact on the financial reports as it manages an unlikely circumstance in accounting.

According to Badertscher (2011), the information theory asserts that two groups (supervisor and shareholders) have access to several information. It depicts manners that is consequential, in this instance, the supervisor selects what to reveal and mode of transmission of the financial information and the users of that information have got to decide just how to figure out the signal.

Figure 1: Conceptual Framework

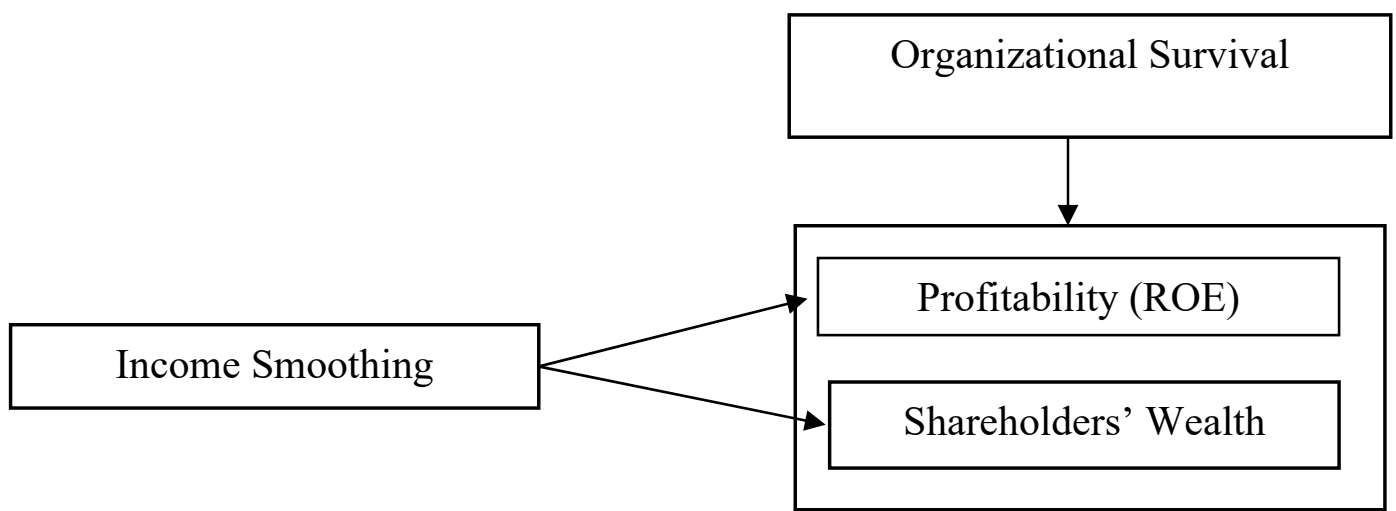

Conceptual Framework on the relationship between Income Smoothing and Organizational Survival in Nigeria Source: Conceptualized by the Researcher (2020)

Having comprehensively examined literature on income smoothing and organizational survival, the scholar originated figure 1 as a prototype of the linkage between income smoothing and organizational survival measured by profitability and shareholders wealth. 


\section{Income Smoothing}

According to Ibrahim (2009), income smoothing is the procedure of decreasing the reported revenues of a firm in an effective period and postponing them to unprofitable periods in an attempt to depict a "steady income stream" for many years. This is feasible due to the elasticity of matching concept, and sponsors desire it as it professes a steady, solid and expanding company. Additionally, that supervisor obtains much better in case of profit-sharing system between supervisors and owners. Income smoothing can be divided splitted into "real" and "artificial" smoothing, (Ujah \& Brusa, 2011). In real smoothing, certain experience can be postponed to the subsequent period e.g. advertising, while artificial smoothing is using, change in income with various plans from one period to the other e.g. depreciation method.

Companies generally like to report a constant trend of development in profit instead of to reveal unpredictable revenues with a collection of remarkable fluctuations. This is attained by making needlessly high stipulations for obligations versus property worth's in great years to make sure that these specifications can be minimized, therefore boosting reporting revenues, in bad years. It likewise stays clear of elevating prospects so high, in excellent years that the business is not able to supply what is ultimately called for. Contrary to this, it is discussed that:

i. If the trading problems of a company remain unstable, then shareholders have the right to know this.

ii. Income smoothing might hide long-lasting adjustments in the profit trend.

In nations with extreme conventional accounting systems, the income smoothing impact can be especially noticeable as a result of the high degree of stipulations that accrue. Cornett et al., (2009) examine a German instance. One more predisposition that often occurs is called 'big bath' accounting where a firm making a negative loss, looks forward to take full advantage of the documented loss in that year to make sure that future years will certainly show up much better. A variation of income smoothing is to adjust profit to relate to prediction. Fox (1997) narrates on exactly how accounting procedures at Microsoft are conceived within the standard accounting policies to match stated earnings to profit predictions. A huge port of the profit is acceded to the forthcoming years to cover up likely upgrades and client assistance expenses whenever Microsoft sells a software program. This completely commendable, and extremely traditional, accounting procedure suggests that future earnings are simple to forecast. Furthermore, business supervisors might maintain an income-boosting accounting procedure change in hand to divert focus from unwanted information.

According to Amat et al. (1999) innovative accounting might help retain or improve a business share value by minimizing the obvious amounts of borrowing, thus making the business less vulnerable to risk, and by developing the look of a reliable profit movement. This aids the business to obtain capital from brand-new share concerns, present their own share in takeover bids, and withstand requisition by other companies. Nonetheless, where the supervisors participate in "insider dealing" in their business's shares, they can make use of innovative accounting to postpone the launch of information, therefore improving their possibility to gain from inside knowledge.

It ought to be kept in mind that in an efficient market, professionals would not be tricked by superficial accounting options. Certainly, the attentive professional will see income enhancing accounting tools as a likely indication of vulnerability. A further motive for innovative accounting occurs as businesses are subjected to different kinds of legal rights, constraints and restrictions based on the quantities stated in the financial statement.

\section{Organizational Survival}

Organizational survival and development are implied managerial objectives, necessitating financial investment power and capital (Jones \& Bartlet, 2011). An organization that does not have survival as a key purpose or aim needs to have a re-think. The aim of organizational survival reinforces all other objectives. Focusing on this objective adds to the fulfillment and accomplishment of other organizational objectives (Gross, 1968).

Gross suggested that the idea of survival is an unwritten law of every organization. This implies that every organization must see survival as an outright requirement for offering any type of interest whatsoever. The principle of organizational life process is designed from the pattern seen in living microorganisms. In the contrary path, organization is examined in stages of evolution and expansion as opposed to in sequential years. The stages are connected in an unpronounced and refined way, yet it is important keeping in mind that not every organization shows the attributes of each stage as it advances.

\section{Measures of Organizational Survival Organizational Profitability}

The term profitability is described as the capability to make revenues gradually over an extended period of time. Profit itself has various significance to various individuals. The term profit has different assumptions to owner, accounting professionals, profits authority and financial expert. Profit is occasionally taken as return accumulating to shareholders. To a commoner, the term profit describes all profits that streams to the capitalist. 
To an accounting professional, profit pertains to proceeds surplus of receipts gathered out of expenses from both production and various other general overhead (Patel, 2015).

Profitability is the only sensible measures of return from funds financed in the business. It is computed in regards to market share, which has actually been secured for an assigned duration. (Patel, 2015). Profit is just one of the significant factors for venturing into commerce. Profitability consequently, implies a state of generating a gain or the level to which an organization is lucrative.

Profitability is the main objective of all organization projects. Without profitability the business will certainly not make it through in the future. Alternatively, a trade that is very rewarding has the capacity to compensate its proprietors with a sizable return on their financial investment (Rankin et al., 2012). According to Okike (2009), attaining appropriate financial outcomes and efficiency is a must, or else the organization's financial standing can startle lenders and investors, harm its capacity to finance vital projects and maybe also place its actual survival in jeopardy.

This makes computing previous and existing profitability and forecasting future profitability a really essential matter. Profitability is consequently recognized as a measure for organizational efficiency. It might be stated in regards to after-tax income and earnings per share or return on investment. An array of profitability quotients can be utilized to evaluate the financial sustainability of the trade but this paper implemented return on investment (ROI) as a step of profitability.

\section{Shareholders' Wealth}

Investor wealth maximization presently has been an emphasis for all corporations as priority, amid further trade concerns such as commercial societal obligations. Abubakar, Abdu and Abdulmaroop (2014) described investor wealth as the predicted potential incomes to the firm vendors computed from their current value. These incomes generally exist in the variety of bonuses paid occasionally and profits from the transacting of stock transactions. They additionally emphasized that bonuses are paid to conventional owners or investors out of company proceeds.

In their research performed on listed companies in Nigeria, it disclosed that adjustments in bonus payment could be applied to forecast stock value activity which subsequently have an effect on investors wealth. This financial information is extractable from the profit and loss account. In addition, they disclosed that activity in firm profits affect movement in the prices of stock; financial accounting information on capital has a positive effect on share costs which as a result influence shareholders' wealth. Nonetheless, share costs hinge on security and development of the economic system.

According to Rankin et al., (2012), production and maximization of investor's wealth are the brand-new standard of corporate and primary purpose of companies presently. Commercialism imposes the duty of producing and making the most of shareholders' wealth. Investors' wealth is valued, making use of the stock rate having taken into factor the timing and the danger related to future earnings to be gotten by the shareholders. They directed that shareholders' wealth can additionally be gauged in various other kinds such as return on equity, return on assets and the efficiency proportions. Shareholders' wealth depends upon numerous elements such as techniques made use of two value stock and approaches of paying out repayments.

Sun and Rath (2010), stresses that a much more differing earnings possibility is unable to maintaining a greater degree of bonuses as likened to a steady earnings stream. Inconsistent dividends impact shareholders' capitalization charges and show entire riskiness of the firm. They subsequently influence subjective potential customers of the financiers for feasible results of future dividends and furthermore impact the worth of the stock of the firm. Beneath the environments of unpredictability, the theory of market balance verifies that smoothing of earnings shows a deliberate effort to reduce covariance of awaited return with revenues on the profile of the marketplace by balancing the recurring stated returns of a firm.

\section{Empirical Review}

There are numerous researches made to uncover this common habit of income manipulation and to record its trend persuaded by various market scenarios. These researches explicitly stress that, in general, income is managed towards the market prospects but diligently due to the potential estimates of the earnings. The following report essentially puts the beam on several issues and circumstances, which steer the supervisors to engage in the practice of earnings manipulation with the intention of realizing their aims of coordinating the marketplace.

Jin and Myers (2006) reported that supervisors keep back a fraction of the organization's cash flows because of absence of absolute clarity with reference to profitability of the company. Supervisors may possibly control earnings to overwhelm the interim losses to protect their statuses, in order to avoid revealing negative performance. Yet, supervisors could be unwilling to conceal any further losses if performance was entirely worse.

Beatty and Harris (1999); Beatty, Ke and Petroni (2002) observed that the type of influence of a business, its stage of obligation combined with its listing and sizes are the major basis for flattening income. Taktak, 
Shabou and Dumontier (2010) concluded in their research that several banks deliberately flatten their revenues either by using loan loss stipulations or selling trading securities. They opined that banks involve themselves more in real income smoothing than artificial income smoothing. Etemadi and Sepasi (2007) studied the correlation linking income smoothing methods and businesses' value in Iran and established that small businesses have a larger predisposition to level income than bigger businesses. Ezeani, Ogbonna, Ezemoyih and Okonye (2012), researched on the influence of creative accounting on the job performance of Accountants (auditors) in financial statement in Nigeria and found that supervisors in non-profit businesses may have motivations in influencing their stated ratios as sponsors use them to establish donation choices.

Iatridis and Kadorinis (2009) observed that those businesses which required cash and stand in front of financial difficulty would plump for income management on the way to increase their accounting figures in other to motivate the shareholders and funds suppliers subsequently. They discovered that revealing the accounting information about businesses' financial choices and performance would reduce the level of income falsification and force investors to make informed decisions Furthermore, earnings management was employed by businesses that used to breach debt contracts to avoid financial woes and disappointing the creditors. Supervisors tend to use earnings management to boost firm operation, increase their reward and sustaining or surpassing the projections of financial experts'. Consequently, the research resolved that businesses that engage in earnings management generally show signs of bigger size, better leverage, lesser growth, and lower profitability. Sanyaolu, Onifade and Ajulo (2017) conducted an empirical investigation on the Influence of Earnings Management on Dividend Policy in Nigeria: An Empirical Note. The outcomes disclosed that earnings management has adverse correlation with dividend policy of a firm and it is not essential in the determination of dividend payment of every firm.

Consequently, Gunny (2010) analyzes the future operating efficiency of companies that utilize earnings management to simply fulfill earnings standards. After managing for size, efficiency development chances, and market, the research uncovered that earnings management methods were favorably connected with companies simply fulfilling earnings standards. Additionally, Okike (2009), Ajibolade (2008) and Bakre (2007), have actually pointed out proofs of income smoothing in the financial market. The scholars highlight functional methods experts' bolsters income smoothing in order to provide an incorrect image of firm efficiency, which is great. The results of the study highlighted an essential link between sponsors defense and the value of accounting earnings reported to market contributors, and enhance both financial study that deal with the value of corporate coverage as exogenous. Nejad, Zeynali and Alavi (2013) researched on the exploration of income smoothing on firms registered on the Tehran stock exchange within a 9-year period 2001-2009 using index Eckel with a sample of 132 and found smoothing engaged on three levels i.e. net profit, gross profit and operating profit.

In summary, income smoothing is conducted in several ways by different corporations, nonetheless, the motive for trying to smooth income remains unchanged, which is to handle variations in revenues due to its instability and to enhance organizational productivity.

\section{Methodology}

This segment addresses the modus operandi of this work, that is, the approach, processes and techniques the scholar exerted in the study. The thought behind this segment is to elucidate on the methods used in compiling and analyzing the data in this research.

\section{Research Design}

The study embraces the ex-post facto and cross-sectional study design. This research design is useful in examining the relationship that exists between variables. It is an approach that is particularly useful when evaluating the inter-relationship among a number of variables at a particular point in time. The cross-sectional research study design tries to define and discuss the specific influence of the independent variables on the dependent variable.

\section{Population and Sample Size}

Baridam (2001) affirms that the target populace is the total populace to which the findings of the research study apply. The populace of this research study (as seen in the table beneath) encompassed the whole one hundred and sixty-eight (168) companies from eleven (11) divisions and fifty-seven (57) sub-divisions quoted on the Nigerian Stock Exchange (NSE) as at 31st December, 2018. Based upon the aims of the research study, the purposive sampling method was used, where a unit of 20 companies (that is, five companies each from the four sectors highlighted in red in the table below) from four (4) divisions and eleven (11) sub-divisions were chosen. Purposive sampling (additionally referred to as judgmental, discerning, or subjective sampling) is a nonprobability model that is chosen based on the attributes of a populace and the aim of the research study. 
Table 1: Summary of Quoted companies by sectors and sub-sectors as at 31/08/18

\begin{tabular}{|l|c|c|}
\hline Sectors & Number of sub-sectors (industries) & Number of companies \\
\hline Services & 14 & 22 \\
\hline Consumer Goods & $7(3)$ & $24(5)$ \\
\hline Construction/Real Estate & 6 & 8 \\
\hline ICT & 6 & 9 \\
\hline Financial & $5(3)$ & $53(5)$ \\
\hline Oil \& Gas & $4(2)$ & $10(5)$ \\
\hline Industrial Goods & $4(3)$ & $17(5)$ \\
\hline Natural Resources & 4 & 4 \\
\hline Healthcare & 3 & 10 \\
\hline Agriculture & 3 & 5 \\
\hline Conglomerate & 1 & 6 \\
\hline Total & $57(11)$ & $168(20)$ \\
\hline
\end{tabular}

Source: Nigerian Stock Exchange

\section{Sources of Data and Data Collection Techniques}

The research relied significantly on secondary data. Data compilation was performed by documented review wherein financial accounts and records were analyzed. The data required for this research study were sourced from the Nigerian Stock Exchange, financial disclosures of the chosen listed firms. The data associating with profitability, shareholders wealth and income smoothing were drawn from the financial statements of the experimented 20 firms listed on the Nigerian Stock Exchange (NSE). The empirical evaluation focuses on the duration of twelve (12) years from 2007 to 2018. The firms were chosen from the financial, consumer goods, industrial goods as well as the oil \& gas industry (see table listed below). Since the research is cross-sectional study, it involves data from various divisions/industry of the NSE market. The quoted companies consist of:

Table 2: Firms included in the study sample by economic and industry sector

\begin{tabular}{|l|l|l|}
\hline Company Name & Sector & Sub-sector \\
\hline Dangote Flour Mills Plc & Consumer Goods & Food Products \\
\hline Honeywell Flour Mill Plc & Consumer Goods & Food Products \\
\hline Nigerian Brew. Plc & Consumer Goods & Beverages - Brewers/Distillers \\
\hline Golden Guinea Brew. Plc & Consumer Goods & Beverages - Brewers/Distillers \\
\hline Cadbury Nigeria Plc. & Consumer Goods & Food Products - Diversified \\
\hline United Bank for Africa plc & Financial Services & Banking \\
\hline Zenith International Bank Plc & Financial Services & Banking \\
\hline Access Bank Plc & Financial Services & Banking \\
\hline Sterling Bank Plc. & Financial Services & Banking \\
\hline Regency Alliance Insurance Company Plc & Financial Services & Insurance \\
\hline Forte Oil Plc. & Oil \& Gas & Petroleum \& Petroleum Product Distributors \\
\hline MRS Oil Nigeria Plc & Oil \& Gas & Petroleum \& Petroleum Product Distributors \\
\hline Anino International Plc & Oil \& Gas & Petroleum \& Petroleum Product Distributors \\
\hline Oando Plc & Oil \& Gas & Integrated Oil \& Gas Services \\
\hline Japaul Oil \& Maritime Services Plc & Oil \& Gas & Energy Equipment \& Services \\
\hline Meyer plc & Industrial Goods & Building Materials \\
\hline Berger paints plc & Industrial Goods & Building Materials \\
\hline Paints and Coatings Manufactures Plc & Industrial Goods & Building Materials \\
\hline Austin Laz \& Company Plc & Industrial Goods & Electronic \& Electrical Products \\
\hline Beta Glass Plc & Industrial Goods & Packaging/Containers \\
\hline Source Nigeran Stock Exchange & & \\
\hline
\end{tabular}

Source: Nigerian Stock Exchange

\section{Model Specification}

For the aims of this research study to be accomplished, the empirical designs for the research study are mentioned as follows:

$\mathrm{PR}=\mathrm{f}(\mathrm{IS})$...

$\mathrm{SW}=\mathrm{f}(\mathrm{IS})$

Explicitly, the econometric method of formula (i) as well as (ii) exists as follows:

$\mathrm{PR}=\mathrm{ao}+\mathrm{a}_{1} \mathrm{IS}_{\mathrm{t}}+\varepsilon$ (iii)

$\mathrm{SW}=\mathrm{bo}+\mathrm{b}_{1} \mathrm{IS}_{\mathrm{t}}+\varepsilon_{1}$ 
Where:

$\begin{array}{lll}\text { PR } & = & \text { Profitability } \\ \text { SW } & = & \text { Shareholders Wealth } \\ \text { IS } & = & \text { Income Smoothing }\end{array}$

Equation (iii) and (iv) examines the extent at which income smoothing affects organizational survival in Nigeria. Income smoothing is the independent variable while profitability and shareholders' wealth are the dependent variables. Based on earnings management theory, it is expected income smoothing will have positive impact on the measures of organizational survival in the short run and negative effect on the long run. Income Smoothing is proxied by steady trend of growth in profit. Shareholders' wealth is measured by return on investment. Organizational profitability is measured by return on equity.

\section{Method of Data Analysis}

The research study embraced the Ordinary Least Square (OLS) regression evaluation as the method of data evaluation. The OLS regression technique assists to analyze just how the explanatory variable (income smoothing) influences the explained variable (organizational survival). The OLS multiple regression was embraced since it is the ideal method for exploring the precise correlation between independent as well as dependent variables (Gujarati, 2009). The Eview 9.0 analytical software applications was employed to analyze the data. To confirm that our model is statistically and also econometrically acceptable, we performed diagnostic test such as goodness fit (R-squared, F-test, t-test and so on). However, preliminary analysis such as the descriptive statistics and correlation analysis were also conducted.

\section{Data Presentation and Analysis \\ Data Presentation}

The table beneath reveals the mean cross-sectional yearly data from the chosen quoted firms in the Nigerian Stock Exchange.

Table 3: Average cross-sectional annual data from the studies sample firms

\begin{tabular}{|l|l|l|l|}
\hline Year & Income smoothing (IS) (N) & $\begin{array}{l}\text { Profitability (PR) proxied by EPS } \\
(\%)\end{array}$ & $\begin{array}{l}\text { Shareholders wealth } \\
\text { proxied by DPS (\%) }\end{array}$ \\
\hline 2007 & 110.04 & 1249.4 & 8.39 \\
\hline 2008 & 123.67 & 104.45 & 9.23 \\
\hline 2009 & 125.50 & 113.82 & 9.90 \\
\hline 2010 & 13.27 & 9.59 & 3.67 \\
\hline 2011 & 20.57 & 23.46 & 29.52 \\
\hline 2012 & 73.56 & 23.46 & 78.74 \\
\hline 2013 & 117.30 & -5.29 & -77.71 \\
\hline 2014 & 213.44 & 25.47 & 21.08 \\
\hline 2015 & 72.57 & 56.78 & 15.39 \\
\hline 2016 & 214.29 & 139.78 & 73.99 \\
\hline 2017 & 28.01 & 78.50 & 19.90 \\
\hline 2018 & 28.85 & 80.86 & 20.50 \\
\hline
\end{tabular}

Source: Author's compilation from studied sampled firm's financial statements from NSE

Unit Root Test

Table 4: Augmented Dicky Fuller Results

\begin{tabular}{|l|l|l|l|l|}
\hline Series & ADF Test Statistic & $\mathbf{5 \%}$ Critical Values & Probability & Remarks \\
\hline IS & -5.228630 & -3.212696 & $1(1)$ & S \\
\hline PR & -17.50661 & -3.175352 & $1(0)$ & S \\
\hline SW & -4.202819 & -3.175352 & $1(0)$ & S \\
\hline
\end{tabular}

Source: Eviews 9.0, where $S=$ Stationary

The outcome in table 4 , at $5 \%$ level of significance reveals that PR and SW are stationary at levels given that their critical values are greater in absolute terms than their Augmented Dickey Fuller (ADF) test statistics. IS was non-stationary at levels given that its critical value is lower in absolute terms than its Augmented Dickey Fuller (ADF) test statistics. However, at first difference, IS was stationary at 5\% level of significance.

\section{Data Analysis}

\section{Trend Analysis}

The trend analysis consists of all the variables reflected in the research. These consist of Income Smoothing (IS), Profitability (PR) and Shareholders' Wealth (SW). The trend analysis of the variables is captured graphically 
from figure 1-3.

Figure 1: Trend of Income Smoothing (IS) covering 2007 - 2018

IS

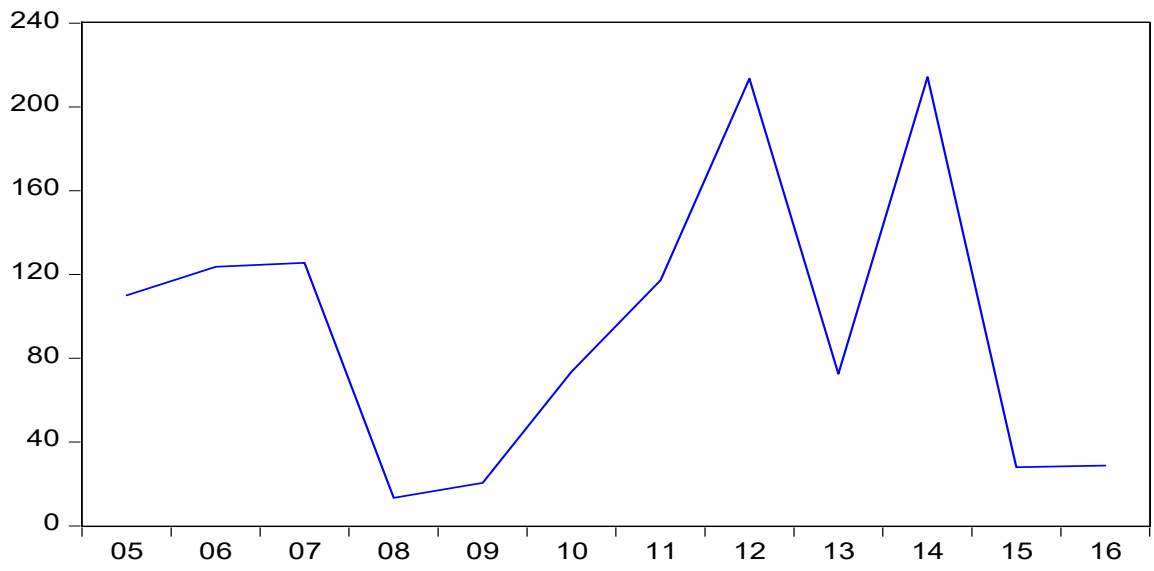

Source: Author's Presentation

Figure 1 reveals the trend of the Income Smoothing (IS). As can be viewed from the graph, there has actually been sharp increase and decrease in IS. In 2007 the valuation of IS stood at 110.04 . This value increased to 123.67 in 2008 and significantly reduced across the board to 13.27 in 2010 . IS reaching its top in 2014 as it was 213.44 and dropped to 28.01 in 2017. Between 2017 and 2018, IS valuation was low and steady.

Figure 2: Trend of Profitability (PR) covering 2007 - 2018

\section{PR}

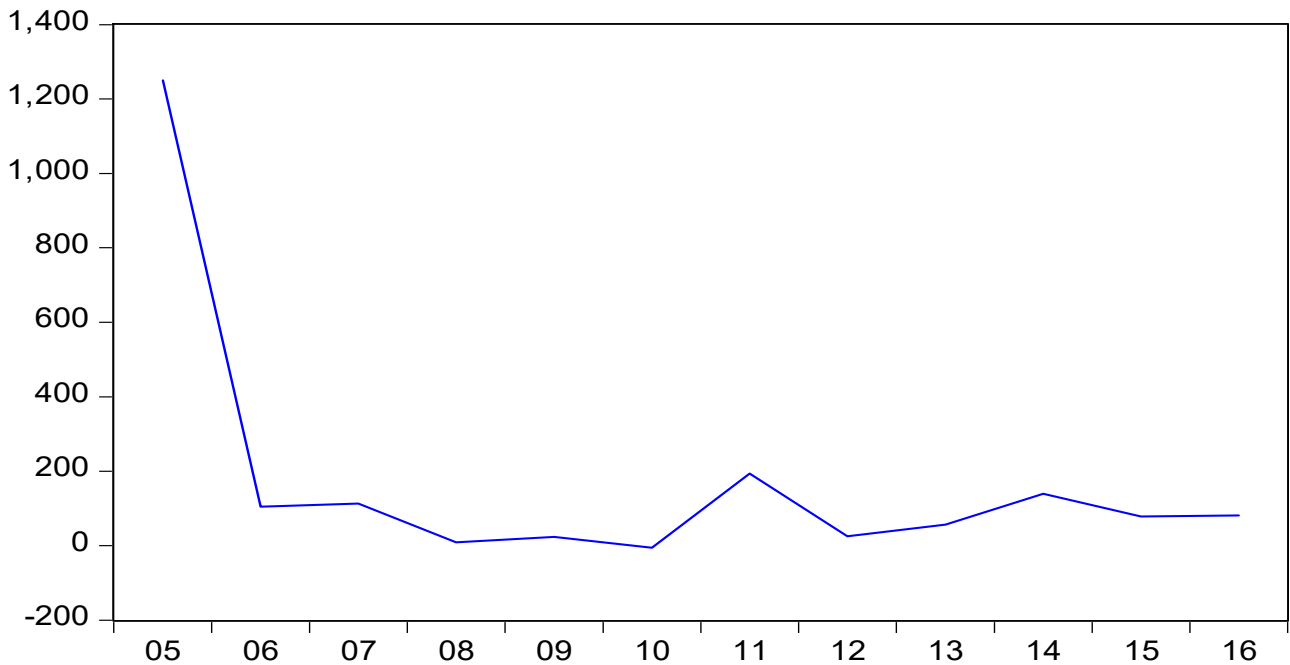

Source: Author's Presentation

Figure 2 reveals the trend of Profitability (PR) represented by earnings per share (EPS). As can be viewed from the graph, there was a keen reduction in earnings per share between 2007 and 2008 as the value fell from N1249 in 2007 to N104.456 in 2008. Beyond this period, there was a steady and consistent increase and decrease in earnings per share. 
Figure 3: Trend of Shareholders' Wealth (SW) covering 2007 - 2018 SW

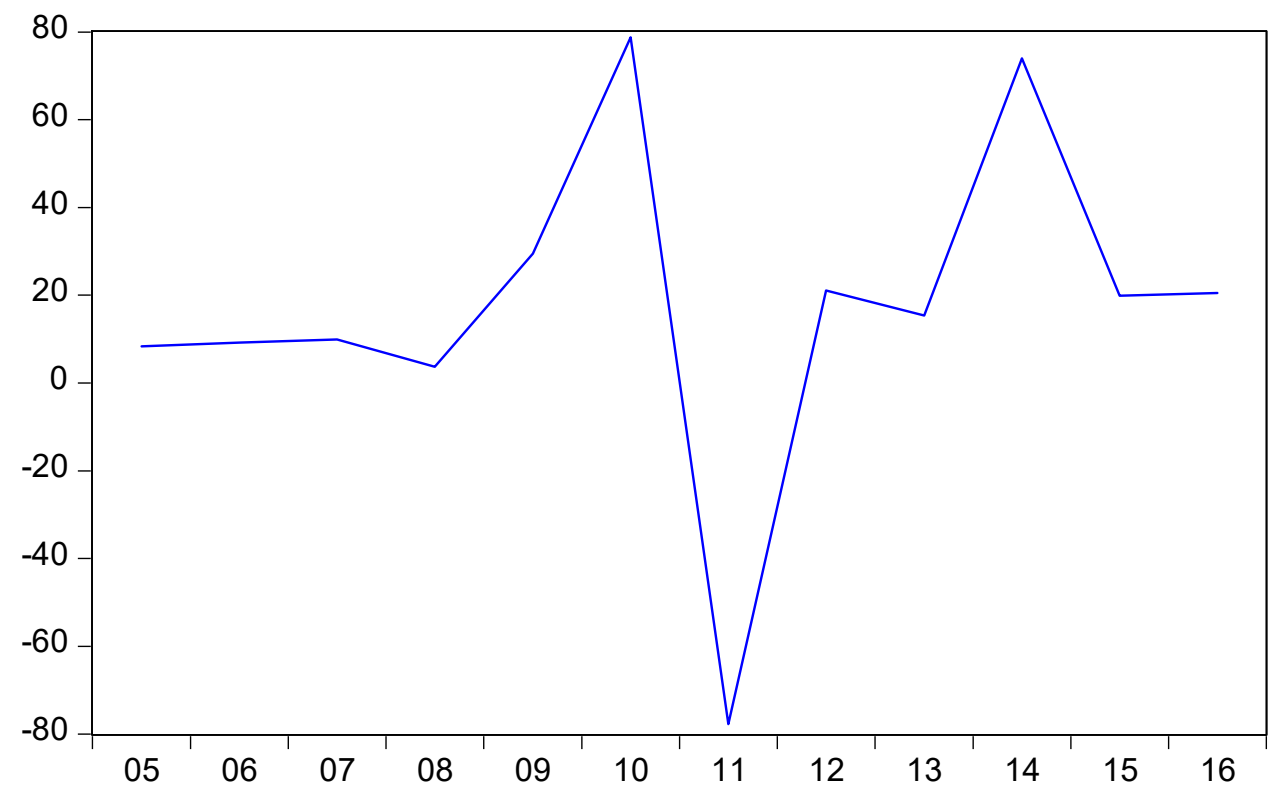

Source: Author's Presentation

Figure 3 reveals the trend of Shareholders' Wealth (SW). The trend analysis revealed that SW reached its optimal in 2012 averaging N78.74 million and got to its lowest in 2013 averaging a negative N77.713 million. The 2013 value indicates a severe loss of shareholders' wealth or investments.

\section{Static Regression Results}

Table 5: Estimated Regression Result

Dependent Variable: PR

Method: Least Squares

Date: 10/08/20 Time: 02:52

Sample: 2007-2018

Included observations: 12

\begin{tabular}{|l|l|l|l|l|}
\hline Variable & Coefficient & Std. Error & t-Statistic & Prob. \\
\hline C & 2974.709 & 316.5293 & 9.397594 & 0.0001 \\
\hline IS & -0.342299 & 0.341122 & -1.003450 & 0.3544 \\
\hline R-squared & 0.974442 & Mean dependent var, & 172.5841 \\
\hline Adjusted R-squared & 0.953143 & S.D. dependent var. & 344.0304 \\
\hline S.E of regression & 74.47031 & Akaike infor criterion & 11.76553 \\
\hline Sum squared resid. & 33274.96 & Schwarz criterion & 12.00798 \\
\hline Log likelihood & -64.59319 & Hannan-Quinmn criter. & 11.67577 \\
\hline f-statistic & 45.75155 & Durbin -Watson state & 11.67577 \\
\hline Prob (F-statistic) & 0.000106 & & 2.01456 \\
\hline
\end{tabular}

Source: Eviews 9.0

The static regression result in Table 5 indicated that profitability proxied by earnings per share is negatively related to Income Smoothing (IS), given the negative signs of its coefficient. The results imply that increase in the use of IS will result in decrease in organizational profitability or earnings per share by approximately 0.3423 . The t-statistic further revealed that IS was not statistically significant in affecting organizational profitability in Nigeria. The coefficient of determination also shows the explanatory power of the model. The value of the adjusted $\mathrm{R}^{2}=0.953$ indicates that approximately 95.3 percent change in organizational profitability is explained by changes in the explanatory variables while the remaining 4.7 percent change in organizational profitability is explained by variables not included in the model which are accounted for by the stochastic term. The Durbin Watson statistic indicates the absence of serial correlation. 
Table 6: Estimated Regression Result

Dependent Variable: SW

Method: Least Squares

Date: 10/08/20 Time: 02:56

Sample: 2007-2018

Included observations: 12

\begin{tabular}{|l|l|l|l|l|}
\hline Variable & Coefficient & Std. Error & t-Statistic & Prob. \\
\hline C & 88.66520 & 209.2947 & 0.423638 & 0.6866 \\
\hline IS & 0.058911 & 0.22556 & 0.261183 & 0.8027 \\
\hline R-squared & 0.122812 & Mean dependent var, & 17.71996 \\
\hline Adjusted R-squared & 0.068178 & S.D. dependent var. & 38.82936 \\
\hline S.E of regression & 49.24106 & Akaike infor criterion & 10.18064 \\
\hline Sum squared resid. & 14548.09 & Schwarz criterion & 11.18064 \\
\hline Log likelihood & -59.62911 & Hannan-Quinmn criter. & 10.84842 \\
\hline f-statistic & 0.168007 & Durbin -Watson state & 2.149818 \\
\hline Prob (F-statistic) & 0.965329 & & \\
\hline
\end{tabular}

\section{Source: Eviews 9.0}

The static regression result in Table 6 showed that Shareholders' Wealth (SW) proxied by dividend per share was positively related to IS as shown by the signs of its coefficient. The meaning of the positive relationship between SW and IS indicates that an increase in IS will result in increase in Shareholders' Wealth by approximately 0.0589 .

The t-statistic further revealed that IS was not statistically significant in affecting SW in Nigeria since its tstatistic value is lower than the critical value at $5 \%$ level of significance. The coefficient of determination also shows the explanatory power of the model. The value of the adjusted $\mathrm{R}^{2}=0.068$ indicates that approximately 6.8 percent change in shareholders' wealth is explained by changes in the explanatory variables while the remaining 93.2 percent change in shareholders' wealth is explained by variables not included in the model which are accounted for by the random term. The Durbin Watson statistic indicates the absence of serial correlation as the value approximates to 2 .

\section{Income Smoothing and Organizational Survival}

Income smoothing and organizational survival continues to be the subject discoursed in this segment. The outcomes in Tables 5 and 6 suggested that income smoothing is adversely connected to organizational profitability and favorably associated to shareholders' wealth. It was further observed that income smoothing is not statistically important in affecting profitability and shareholders' wealth. The outcomes follow the findings of Reza (2011), in a research named "Study of the relationship management and profitability of listed companies in Tehran Stock Exchange" asserted that income smoothing amplifies shareholders' wealth. The outcomes were slightly dissimilar in regards to the connection between income smoothing and profitability as Reza (2011) reported a positive correlation. Mashayekhi, Mehrani, Mehrani and Karami (2006) unearth that quoted companies in Tehran Stock market (TSE) do income smoothing when their accomplishment is poor and they have a tendency to select income enhancing accounting techniques. Mehrani and Arefmanesh (2008) supply some proof that income have had a lower feat steering to a greater stimulus, compared to non-income smoother in TSE.

Based upon the literary works and results, firms with smoothed earnings are a lot more appealing to financiers than firms with highly erratic earnings. However, we assume that there is likewise a second narrative on companies that level their reported earnings. By leveling their revenues, companies transmit signals to market, amplify their economic achievement and induce contractual outcomes that hang on reported accounting customs. In short period (around reporting time), it is likely that income smoother and/or companies supervisor accomplish their objective (upsurge in their uncommon earnings, short-run returns, and prevention of losses) but in extended period, investors get further information (from useful information sources) regarding the accurate monetary and economic status of those companies and thereafter remedy their choices. In this state, we anticipate that the degree of long-run stock return and unusual stock return decrease. Hence, it is anticipated that there is an adverse correlation between income smoothing and long-run stock return or profitability and shareholders' wealth. To put it simply, it is anticipated that the income smoother and companies' supervisor receive depleted long-run return and abnormal return than other companies.

\section{The findings are summarized thus:}

i. Income smoothing has a negative and statistically insignificant effect on organizational profitability $\left(\mathrm{a}_{1}=-0.3423, \mathrm{t}_{0.025}=-1.0035\right)$, and 
ii. Income smoothing has a positive and statistically insignificant effect on shareholders' wealth $\left(b_{1}=\right.$ $\left.0.0589, \mathrm{t}_{0.025}=0.2612\right)$.

\section{Conclusion}

Income smoothing, be unethical or illegal as it involves taking cognizance of the accounting policies may impact negatively on organizations in the long run. Income smoothing may result in a positive or negative outcome in organizations but the timing should, however, be appropriate so as to avoid an outcome that is negative. Income smoothing may be carried out for several reasons; however, this has been seen not to happen without manager's involvement. The manager either agrees to manipulate account for the shareholders or manipulate it against them. Review of financial statement by auditors can help reduce the level of income smoothing practices that are detrimental to organizations survival. The shareholders should equally be active in their participation of the organization affairs especially at the various meeting they are privileged to attend.

\section{Recommendations}

Based upon the theoretical presentation and the findings of the research, the list below recommendations are made.

1. Although the partnerships between some variables are not substantial, proper actions must be established for appropriate assessment, exam and scrutinization of financial declarations of quoted companies. Ample treatments for very early discovery of income smoothing methods ought to additionally be established before income smoothing techniques will certainly have a significant and wonderful unfavorable influence on their efficiency.

2. The accounting specialist bodies (ICAN) need to additionally seek for the total independence of the accounting professionals from the supervisors of the companies, wherein the accounting professional is utilized by an independent body and records to the very same independent body besides the board of supervisors.

3. Accounting method and detraction can damage any kind of organization, there is the demand to bring back stability and public self-confidence to accounting procedures, the accounting professionals need to be enhanced to react swiftly to the outright misuses and negligence on the planet of organization, enforce assents on wrongdoers and make certain total conformity of the permissions on debtors.

\section{Contribution to Knowledge}

Based upon the findings, it can be stated the research study adds to the expanding body of knowledge on the impact of income smoothing on organizational profitability and also shareholders' wealth. The study enlarged the boundaries of information/data as it is a good reference material for scholars and academics in the discipline of accounting, banking, finance etc.

\section{References}

Abubakar, A., Abdu, Y. M., \& Abdulmaroop, O. A. (2014). Loan loss provision and earnings management in Nigerian deposit money banks. Mediterranean Journal of Social Science, 5(17), 1 - 12.

Ahmadian, A. S., \& Nazaripour, M. (2015). The Relationship between earnings management and financial ratios (A panel data approach). IJABER, 13(2), $12-23$.

Bergstresser, D., \& Philippon, T. (2006). CEO incentives and earnings management. Journal of Financial Economics, 80(3), 511-529.

Donaldson, L., \& Davis, J. (2009). Stewardship theory or agency theory: CEO governance and shareholder returns. Australian Journal of Management, 16(1), 49-65.

Idialu, O. (2008). The influence of takeover protection on earnings management. Journal of Business Finance and Accounting, 35(3-4), 347-375

Kang \& Kin, E. E. (2011). Discretionary behaviour with respect to allowances for loan losses and the behaviour of security prices. Journal of Accounting and Economics, 22(1-3), 177-206.

Sloan, R. G. (1996). Do stock prices fully reflect information in accruals and cash flows about future earnings? Accounting Review, 71(3), 289-315.

Sunday, L., \& Rath, S. (2012). Earnings management Research: A review of contemporary research methods. Global Review of Accounting \& Finance, 1, 121-135.

DeFond, M., \& C. Park, (1997). Smoothing income in anticipation of future earnings. Journal of Accounting and Economics, 25(2), 115-139.

DeFond, M., \& Jiambalvo, J. (1994). Debt covenant violation and manipulation of accruals. Journal of Accounting and Economics, 17, 145-176.

Dechow, P. M., \& Dichev, I. D. (2010). The quality of accounting and earnings: The role of accrual estimation errors. The Accounting review, 77(2) 35-59 
Freeman, R. E. (1984). Strategic management: A stakeholder approach. London: Pitman.

DeAngelo, H., DeAngelo, L., \& Skinner, D. (1996). Reversal of fortune dividend signaling the disappearance of sustained earnings growth.Journal of Financial Economics, 40, 341-371.

Dechow, P. M., \& Dichev, I. D. (2002). The quality of accounting and earnings: the role of accrual estimation errors. The Accounting review, 77(2) 35-59

Dechow, P. M., Richardson, S. A., \& Tuna, I. A. (2002). Are small profit firms boosting accruals to avoid losses and are they different from small loss firms? Working paper, University of Michigan.

Dechow, P. M., Sloan, R. G., \& Sweeney, A. P. (1996). Detecting earnings management. The Accounting Review, 70, 193-225

Donaldson, L., \& Davis, J. (1991). Stewardship theory or agency theory: CEO governance and shareholder returns. Australian Journal of Management, 16(1), 49-65.

Donaldson, T., \& Preston, L. E (1995). The stakeholders' theory of the corporation concepts, evidence and implications. Academy of Management Review, 20(1), 65-91.

Eckel, N. (1981). The Income Smoothing Hypothesis Revisited. The Abacus, 17(1), 28-40.

Egbunike, A., Ezelibe, C., \& Aroh, N. (2015). The influence of corporate governance on earnings management practices: a study of some selected quoted companies in Nigeria. American Journal of Economics, Finance and Management, 1(5), 482-493.

Hassan, S. U., \& Ahmed, A. (2012). Corporate governance, earnings management and financial performance: A case of Nigerian manufacturing firms. American International Journal of Contemporary Research, 2(7), 114.

Sun, L., \& Rath, S. (2010). Earnings management research: A review of contemporary research methods. Global Review of Accounting \& Finance, 1, 121-135.

McNichols, M. (2000). Research design issues in earnings management studies. Journal of Accounting and Public Policy, 19 (4-5): 313-345.

McNichols, M., \& Wilson, G. P. (1988). Evidence of earnings management from the provision for bad debts. Journal of Accounting Research, 26(3), 1-31.

Mehta, S. \& Srivastavaare, R. (2009). Reasons for corporate governance failures. http/www.indianmha.com/faculty_column/fc974/fc974html (Accessed Feb. 2nd, 2011).

Osisioma, B. C., \& Enahoro, J. A. (2006). Creative accounting and option of total quality accounting in Nigeria. Journal of Global Accounting,2(1), 5-15.

Dechow, P. M., \& Dichev, I. D. (2010). The quality of accounting and earnings: the role of accrual estimation errors. The Accounting review, 77(2) 35-59

Ijeoma, N. (2014). The contribution of creative accounting on economic development. International Journal of Scientific \& Engineering Research, 4(9), 2499-2502.

Isenmila, P. A., \& Elijah, A. (2012). Earnings management and ownership structure: Evidence from Nigeria. Research Journal of Finance and Accounting, 3(7), 24-36. 